\title{
Kosovo Crucified-Narratives in the Contemporary Serbian Orthodox Perception of Kosovo
}

\author{
Emil Hilton Saggau
}

Department for Church History, University of Copenhagen, 2300 Copenhagen S, Denmark; ebs@teol.ku.dk

Received: 25 August 2019; Accepted: 1 October 2019; Published: 16 October 2019

\begin{abstract}
In contemporary Serbian Orthodox texts, Kosovo is often referred to as the Serbian "Jerusalem": a city calling for a Christian defense. All Serbs are bound to heed the call in keeping with the Kosovo "covenant" or "pledge" dating back to the Battle of Kosovo Polje in 1389, when Serbian troops, led by Prince Lazar, were defeated by the invading Muslim Ottoman army. The battle and Kosovo in general have since then assumed a central symbolic role in Serbian nationalism and the Serbian Orthodox Church. Furthermore, it has been claimed that the imagery and narratives of Kosovo were the ideological backdrop for the wars in the Balkans in the 1990s. This article investigates the development of the Serbian narratives and imagery pertaining to Kosovo and their modern form in the Serbian Orthodox Church in order to trace what type of imagery is dominant. The main focus will be on whether and to what extent the narratives of Christian defense and holy Serbian warriors fighting in the name of Christ are dominant. This investigation seeks to discuss whether the Kosovo imagery and narratives are formed upon and influenced by a broader Christian European antemurale myth.
\end{abstract}

Keywords: Serbian Orthodox Church; Kosovo myth; religion and violence; Antemurale Myth

"We are fighting, [ ... ] a new Kosovo battle, but this time we have no venerable Prince and no Holy Cross."-Metropolitan Amfilohije (1999, Kosovo Crucified)

A few months after the war in Kosovo ended in June 1999, the Serbian Orthodox Church published Kosovo Crucified (Serbian: Raspato Kosovo, SOC Serbian Orthodox Church), a book containing a long list of churches that were damaged during the conflict along with the names of missing Serbian clergy and individuals, combined with testimonies and messages from the Serbian Orthodox Church. The book is filled with a message of suffering, loss and misery.

Metropolitan Amfilohije opens his testimony in this book with the quote above, painting the scene of the battle at Kosovo Polje in 1389. In the popular narrative, Prince Lazar is slain as he leads the Christian Serbs towards certain defeat against the advancing Muslim Turkish army. The Serbs lose their grasp on earthly power, but are instead awarded with heavenly power, and are promised that there will be another battle for Kosovo and that Serbia will be resurrected (Judah 2009, pp. 29-47). This was the tale the troops of the newly formed Serbian nation-state were told when they entered the Ottoman and Muslim controlled province of Kosovo in the First Balkan War in 1912. The Serbs thus conquered Kosovo and the land was resurrected in the early twentieth century, and so too was the cult of Lazar (Judah 2009, pp. 36-37). Almost a hundred years later, the tale of Kosovo was told yet again during the reawakening of Serbian nationalism in the dying hours of Socialist Yugoslavia in the 1980s. Slobodan Milošević (1941-2006) and his autocratic regime wielded the symbols of Kosovo and the battle, both as he rose to power, and again in the wars in the Balkans that followed in the 1990s. The Kosovo trope was used to frame Milošević's opponents as the Muslim Turks standing ready to attack the Serbs once more (Judah 2009, pp 327-37). In late 1999, on the ashes of these wars, the metropolitan used the tale of the Kosovo battle to tell of the Serbian suffering at the hands of what 
he called Albanian terror. But the Serbs had by then lost faith in their leaders, so the metropolitan called upon the Western Christian world to remember their 2000 years of Christian history and aide the Christian Serbs "before God, before history and before the modern world" (Amfilohije 1999).

\section{The Christian Bulwark in the Balkans}

Throughout the Balkans and Eastern Europe, various nations and states have depicted themselves as the Christian bulwark against invading Muslim enemies threatening Christianity or a specific culture. In Croatia, the Croats were often cast in various narratives as Catholic Europe's last civilized frontier against the Muslim Turkish "barbarians" or "infidels" during the Habsburg period (Goldstein 2005; Zanic 2005). This image of the threatening Turks was not confined to Croatia, but spread throughout Europe and the imagery of a Christian defense or bulwark to stop the Muslim tide developed in various places including Hungary and Poland (Housley 2003, pp. 29, 131-59). In Serbia, the myth of a Christian bulwark has taken many forms since the Ottoman advance in the fourteenth century, and the Serbs have been depicted as the defenders of Christian Europe against the Muslims, or also as local defenders against American or Habsburg imperialism. As Ana Antic (2005) notes, the Serbian myth of being a bulwark became increasingly dominant in Serbia in the late 1980s and 1990s as a political tool used in order to legitimize Milošević's new Serbian regime and its wars. The Serbs were thus cast as Christian Europe's outer defense against the Muslim Albanians. Albanian paramilitary groups were often referred to as a form of "Turks", thereby alluding to the popular image of the Turkish threat to Christian Europe.

A crucial part of this Serbian nationalist self-image is the story and narratives pertaining to Kosovo and the battle at Kosovo field in 1389. In journalist Tim Judah's seminal work on Serbian history (Judah 2009) as well as in Noel Malcolm's work on Kosovo (1999), it is argued that the Serbian narraritives on Kosovo and the battles are the most influential imagery of the Serbian nation. Malcolm (1999); Judah (2009) and others (Bieber 2002; Ramet 2005; Greenawalt 2001; Edwards 2015) call the Serbian narratives on Kosovo the "Kosovo myth". The Kosovo narratives are argued to be highly influential in Serbia-both on government and in civil society alike-because they are seen as the ideological backdrop for Serbian nationalism and the Serbian war effort in the 1990s (Judah 2009; Malcolm 1999).

The contemporary Serbian nationalist narratives of Kosovo emphasize central fault lines between East and West, Islam and Christendom, and various branches within Christendom seen from the outside. This has made it into a prime example used by Samuel Huntington in his thesis in The Clash of Civilizations (Huntington 1993, pp. 22-49; Huntington 1996). In Huntington's opinion, a cultural wall exists between Western Christianity and Islam, and it runs through the Balkans and Serbian territory.

However, as Florian Bieber (2002, pp. 96-99) points out, the use of the myth in the 1990s and the popularized myth of a wall or fault line in the Balkans arose from the political use and instrumentalization of the myth by the political elites of the Balkans. The Milošević regime's use of the bulwark metaphor regarding Kosovo during its rule might be a mere political rhetorical tool, rather than a reflection of what the Kosovo narrative was to the Serbs and the Eastern Orthodox Church independently of the heated political turmoil of the 1990s. Huntington's $(1993,1996)$ and others' perception of the wall might be a reflection of the Milošević regime's use of the myth, rather than the deeper historical content of the myth in the Serbian Orthodox Church.

This article is therefore an investigation of the existence of the Christian bulwark and wall metaphors-often called the antemurale myth — as well as an analysis of the myth's structure and its main themes in the Serbian and especially the contemporary Serbian Orthodox Church's narratives about Kosovo. The article aims to determine whether the bulwark, wall and holy warrior themes existed in the Kosovo narratives before the 1990s. The analysis will also shed light on whether the antemurale myth and the imagery of holy warriors defending a wall are present in a wider Eastern Orthodox narrative, in which Byzantium, Russia and the Orthodox world are viewed as the center of 
the world, in contrast with the antemurale myths in the Croat, Polish or Hungarian national narratives that are bound together with tales of Western Catholicism and its center in the Roman papal seat.

The article consists of three parts, the first being a short introduction to the major contemporary Kosovo narratives in Serbian historiography. The second section is an analysis of how the Kosovo theme was revitalized in the Serbian national romantic period in the nineteenth century and whether these modern versions of the Kosovo narratives contain an antemurale theme. The final part focuses on the Serbian Orthodox Church's contemporary approach to Kosovo before, during, and after the Kosovo War in 1999, in order to discuss to what extent the antemurale theme is still present.

In this article, the terms Serbia and Serbs will be used continually to refer to states and peoples across the span of several centuries. However, it is not intended to be an argument for the existence of a homogenous Serbian nation throughout the entire period. The terms are simply used as a general reference to those states and people, as well as the church, which use the term "Serbian" to describe themselves. The terms arise from within the sources and their content is not critically assessed, because that is not the purpose of this article. They mainly refer to the Serbian nation-state and its conception of its people, and it is from this point of reference that the older medieval sources are interpreted.

\section{The Function and Signs of an Antemurale Myth}

Norman Housley describes the core parts of the bulwark myth in Religious Warfare in Europe, 1400-1536 (2003). He points out that the myth is essentially built on an Old Testament image of a "covenant" entitling a people to holy soil. This entitlement entails the need for a defense in the face of external threat, and in turn, the defenders are warriors of salvation (a variant of a crusader image) whose actions mirror Christ's own salvation of mankind. In the formation of nations and states, this image was projected onto entire nations as a core state-myth (Housley 2003, p. 29). Along the same lines, Pål Kolstø (2005) argues that a certain set of myths has been used in the creation of states and nations in South Eastern Europe. The main function of these myths is the creation of defining lines. According to Kolstø (2005), there are four types of these myths that all play the same role in identity-creation as a way to distinguish between two groups. Kolstø (2005, pp. 3-5) calls the four types sui generis, antiquitas, martyrdom, and antemurale.

The first two types of myths (sui generis and antiquitas) relate to how a people or nation was created. The sui generis myth is a sort of cultural genealogy explaining where a nation rose from, whereas the antiquitas is the idea that a people has always been the inhabitants of a certain place. The third type, martyrdom, is a scheme in which the oppression and suffering of a group is used in order to create an identity based on this suppression in which the oppressed is the moral superior. The last type of myth is the antemurale, which describes how a group of people are the frontline and defenders of a bulwark or wall (murale) for a larger whole. This type is different from the other three because here a certain group acknowledges that they are part of a larger group, e.g., "the West" or "Christendom", rather than differentiates itself from all others. The group identity is instead formed because they are "chosen" to defend the civilized world against chaos. Thus, there is no hard border all the way around the entire group, as in a sui generis myth, but the group is defined by one extreme hard border, and all other borders are de-emphasized. Many such examples are found around Eastern Europe, such as the Polish self-imagery of being Western Catholicism's last stronghold against the barbaric Eastern Russians. Here, the all-defining border is between East and West, and the lines between Poles and other Western nations are de-emphasized (Kolstø 2005, pp. 14-27).

The antemurale myth is characterized by the metaphors of being a bulwark, a wall, and the final outpost of civilization, upholding order against barbaric enemies seeking to impose chaos. In this constant defense of civilization or of a religion, martyrdom and the glorification of the valiant guards come to play a substantial part in the myth. Kolstø (2005) points out that the myth can be fused with religious overtones, so that the nation might be depicted as a group chosen by divine providence to shoulder a heavy burden in a war against chaos. Kolstø (2005, p. 20) further unpacks this image, arguing that "in this martyrological version the antemurale myth acquires messianic overtones: the 
nation is seen as a collective Christ that gives its life for others." There is one crucial difference between Kolstø's description of the myth and Housley's. Kolstø argues that the use of this type of myth to create difference is widespread, and that it is not limited to a specific religious group as it is used by Muslims as well as Christians. In contrast, Housley traces the myth back to the Old Testament and only identifies it with Catholic groups (Hungarians, Croatians and Poles). This may be because Housley's work focusses on Western crusaders and Catholic-dominated groups. He might not be aware of the existence of this type of myth among other religious groups, such as the Muslims and Eastern Orthodox groups, which Kolstø refers too. Housley's description of the myth is, moreover, much more bound to Christianity and the Old Testament, while Kolstø argues that the myth can exist without such religious overtones. Kolstø notes that such a religious theme exists, but that the bulwark myth can also be secularized. An open question is then whether the same biblical references exist in the Eastern Orthodox bulwark myths which are held by the Serbs as do in the Catholic bulwark myths. Another question is whether the Serbs use the same imagery in which their soldiers become images of Christ when they defend their nation. This will be discussed further throughout this article.

\section{The Formation and Rise of the "Kosovo myth"}

In the following section, the contemporary Serbian versions of the national narratives of Kosovo will be briefly introduced. These are often simply referred to as a whole as the Kosovo myth. The purpose of this introduction is to provide a short overview of the dominant imagery, narratives and symbols.

\section{The Myth}

Needless to say, there is nothing called the "Kosovo myth" within the vast body of the Serbian Orthodox Church's (SOC from hereon) literature, liturgies and description of saints. The SOC often speaks of a Kosovo "pledge" or "covenant" which is closely linked to what the church considers its spiritual and physical heritage in Kosovo (SOC Serbian Orthodox Church). The conception of a "Kosovo myth" is instead made up as a description from an outside perspective of a series of narratives and folkloric imagination about Kosovo within and beyond the Serbian Orthodox Church. This framing and analytical concept is an academic construction-and often comes from quite a critical point of view on Serbian nationalism and the SOC. The construction is not homogenous as it often relies on different sources and describes different periods in Serbian historiography. The uncritical use of the concept of a "Kosovo myth" as a homogenous one, and the mixing of the political or religious types of myths and sources without regard to their context and what the myths actually contain, often leads to simplistic claims. Several authors, such as Tim Judah (2009); Noel Malcolm (1999) and Alexander Greenawalt (2001), have been criticized for this. Malcolm has been greatly criticized for trying to disprove the Serbian myths with what he calls "proper history" and in doing so providing grounds for racial and ethnic claims, a discussion Kolstø (2005) unpacks. Others, such as Tim Judah (2009) and Branimir Anzulović (1999), have been criticized for turning the Kosovo myth into an ahistorical myth always present in the Serbian people, thereby indirectly arguing that the Serbians have always been inclined to ethnic cleansing in the name of Kosovo because they are filled with "Ancient Hatred" (Bieber 2002, pp. 97-98).

Therefore, there is not a single "Kosovo Myth", but rather a series of interrelated ones. In order to avoid the pitfalls hinted at above, I will continue to call the Serbian stories (factual and imaginary) of Kosovo narratives, thereby focusing on their content. The actual correlation or instrumentalization of the narratives in relation to the Kosovo War in 1999 or to Serbian nationalism in general is not the focus of this article.

The first of these Kosovo narratives is about the creation of the Serbian Orthodox Church and the Serbian medieval kingdom in part of today's Kosovo. This narrative contains the history of the Serbian dynasty of Nemanjić, who became kings after having been rulers (Zupans) of the region of Raška. The Serbian realm of Raška covered much of today's Kosovo and southern Serbia. Its concrete 
borders are heavily disputed, but its heart was the Stari Ras fortress (Old Raška) on the border between today's Kosovo and Serbia. The Nemanjićs were pivotal in the creation of the Serbian kingdom, which they ruled until the fourteenth century, and the Serbian Orthodox Church, which was founded by two of the first Nemanjićs, St. Sava (1174-1236) and his father Stefan Nemanjić (later canonized as Saint Symeon, d. 1199). In this narrative, the creation of the Serbian medieval state and church is bound to this family, often called the "holy root", and to a series of sites created by them. A major group of these sites are monasteries in today's Kosovo. The SOC archbishopric was moved to Peć in Kosovo in 1253, which later became the residence for the Serbian Orthodox Patriarch up until its final abolition by the Ottomans in 1766. This first narrative's major theme is the portrayal of Kosovo as the home of the Nemanjić dynasty, their state and their church, which in turn makes Kosovo the "holy" cradle of the Serbian people (Pavlovich 1989, pp. 32-94). After the Ottoman conquest in the years after the battle at Kosovo Polje, the SOC's Patriarchate was preserved as an institution in various forms, which many historians have identified as a central factor in the formation of the proto-national Serbian identity (Greenawalt 2001, p. 54).

The second narrative is about the battle of Kosovo Polje in 1389, which is described in a series of folkloric poems, called the Kosovo cycles, and a variety of older ecclesial sources. This narrative was written down and standardized in the romantic period of Serbian nationalism at the end of the nineteenth century by the influential Serbian writer Vuk Stefanovic Karadzic. Karadzic's version, which since became the most widespread version of the narrative, is the story of how Prince (Knez) Lazar Hrebeljanović died as he fought with his army against the invading Ottomans at Kosovo Polje. Despite all the historical debate around what actually took place on that fateful day in 1389, the folk tradition contains a few central traits (Malcolm 1999, pp. 58-80). At the beginning of the narrative, Lazar gives up his grasp on earthly power in order to receive heavenly power. In doing so, he accepts his impending death and the destruction of his realm, as well as Ottoman and Muslim suzerainty over his people. In the poem, he does so when he accepts the news from Saint Elijah who appears to him in the shape of a grey falcon sent from Jerusalem by Mary, the birth-giver of God (Theotokos). Saint Elijah says:

"Lazar! Lazar! Tsar of noble family, / Which kingdom is it that you long for most? / Will you choose a heavenly crown today? / Or will you choose an earthly crown?"

(John and Vuckovic 1989)

Lazar then chooses heaven and gathers together twelve Serbian clerics in order to prepare wine and bread before his final supper. At this event, a Serbian "Judas" reveals himself in the form of Lord Vuk Branković, who accuses the young knight Miloš Obilić of being a traitor. Obilić, enraged by this accusation, rides out alone in a quest to kill the Ottoman sultan. He succeeds but is slain while Branković betrays Lazar on the battlefield. The poem's narrative about Lazar is clearly built on a classical imago Christ scheme, as the story of Lazar mirrors parts of the narrative about Christ. He accepts the message of his impending death and holds a last supper with twelve clerics, and the poem underlines how, in doing so, he becomes a saint. The image of Lazar clearly builds on a classical Eastern Orthodox hagiographical or iconographic scheme of the noble lord who accepts his death and suffering, and in doing so is elevated to martyrdom.

There are two other elements in the story of the battle of Kosovo Polje which became essential to the myth; firstly, that the battle took place on 28 June, which is "Vidvodan" (St. Vitus Day), and secondly, there is the side story of the Kosovo Maiden who seeks her fiancé at the battlefield (in some tradition her fiancé is Obilić), while she washes and weeps for the dead Serbian soldiers, and brings wine and bread to the wounded in a sort of last supper scene. The Maiden became a central figure depicted by many Serbian artists, such as Uroš Predić in his famous 1919 painting The Kosovo Maiden, and is today part of the national personification of Serbia. This narrative about the battle receives its significance mainly because of its revival as a national narrative in the creation of the new Serbian nation-state in the nineteenth century. Until the standardization of the folkloric tradition by Karadzic 
and its application by the poet Njegoš, there was not a uniform tradition and, according to Noel Malcolm, Lazar and the Kosovo battle had little significance in Serbia (Malcolm 1999, pp. 78-80). There are very few concrete references in the original Serbian sources that suggest the existence of an original antemurale myth. However, in the Catholic sources about the battle, both an antemurale and crusader themes are present (Malcolm 1999, pp. 78-80) and fit into the Western Catholic perception of the Muslim advance and threath to Europe (Housley 2003).

The third narrative about Kosovo is the story of the Serbian "Exodus" or migrations from Kosovo in 1689-1692 and again in 1737-1739. The Serbian Orthodox Patriarch of Peć led both migrations from Kosovo to the southern part of the Habsburg realm on today's border between Hungary and Serbia. The background for the migrations was two failed Serbian rebellions against the Ottomans during the many wars between the Ottomans and the Habsburgs. The narrative about the Serbian migration often dwells on the continual struggle for freedom, which time after time led to Serbian suffering and eventually an Exodus from the heart of the Serbian Orthodox Church. This "Exodus" (Serbian: "Velika Seoba" - the great migration) is often described as the final destruction of the Serbian control of Kosovo, after which the region was slowly taken over by Muslim Albanians (Malcolm 1999, pp. 131-41; Pavlovich 1989, pp. 96-101).

These three narratives about Kosovo are all entangled and together reinforce the "Grand" Serbian narrative about the Serbian historical experience in Kosovo. The Kosovo myth is often reduced to the narrative of the battle at Kosovo Polje in 1389. However, the battle only receives its importance through the two other narratives, which tell the tale of what Kosovo is (the Serbian cradle), and how the battle is the first step in the gradual Serbian loss of control over Kosovo (reinforced by the Exodus).

The fourth narrative, which from today's perspective is equally important, is about the significance Kosovo was given in the formative years of the Serbian nation-state in the nineteenth and twentieth centuries. The "spirit from Kosovo" became an ordinary way to speak about the Serbian national character, and the imagery of Kosovo found its way into poems, paintings and national monuments heralded by, among other works, Vuk Karadzic's standardization of the epic of Kosovo Polje (Judah 2009; Mylonas 2003). It is during this period that the Kosovo narratives were given a structured role in which various modern forms of the myth can be identified. These are examined in detail below. The adaptation of the narratives as the basis for the Serbian nation-state also ensured the narratives' influence on Serbia over the course of the following two centuries.

The Serbian Kosovo heroes from the narratives became the ideal Serbian warriors that were depicted in epics, such as the influential epic "The Mountain Wreath" and used during the Serbian uprisings in the nineteenth century and later during the Balkan Wars in 1912. During this period, the formation of the Serbian nation-state and its eventual military conquest of Kosovo in 1912 were interpreted as God's intervention, freeing the Serbs from the Ottoman yoke. The day of the Kosovo Polje, St. Vitus Day, became even more significant after a Serbian student shot the Habsburg Archduke in Sarajevo on this day in 1914. This assassination precipitated the First World War and reinforced the importance of St. Vitus Day for the Serbs (Judah 2009). Malcolm (1999, p. 140) describes how Serbian writers and historians formulated this new Serbian national myth as one with four parts corresponding to the story of Christ. Firstly, Christ is born as Serbia is founded in Kosovo. Secondly, Christ is crucified, which corresponds to Serbia losing the battle of Kosovo. Christ is then dead and buried, like Serbia in the great migration. And finally, Christ rises again, just as Serbia is resurrected as a new state which conquers Kosovo in 1912. This is not a myth of a wall, but a myth of suffering, martyrdom, and resurrection. Here, the Serbs and their nation are portrayed as holy warriors re-experiencing the suffering and resurrection of Christ.

\section{The Emergence of the Modern Kosovo Narratives}

The modern adaptions and popularizations of the Kosovo themes in Serbia almost all take their point of departure from Vuk Karadžić (1787-1864) and Petar II Petrović-Njegoš’s (1813-1851) modernization of the Kosovo narratives. Before their works, the tradition was scattered and had 
not yet been turned into a popular version which could be used in the construction of religious and national identity. In the following section, Karadžić's and Njegoš's works on Kosovo will be briefly outlined, and the presence of an antemurale theme will be discussed.

Karadžić was an influential Serbian folklorist and linguist who published four volumes of Serbian National Songs between 1841 and 1862, which included several songs and poems on Kosovo. He had already published a shorter version of the Kosovo epic in 1815, but the 1841 and 1862 versions contained a selection of what is known as the Kosovo cycle of poems. Karadžić himself lived during the time of the two major Serbian revolts which eventually lead to the formation of a Serbian nation-state (Wilson 1970).

Karadžić, a trained romantic, saw the Serbian folk tradition as the core of the Serbian people which had been transmitted to his time from the Middle Ages. These songs of the people should, in his opinion, be the basis for a Serbian national literature, the existence of which could be used to justify the claim for a Serbian state free of Ottoman control (Greenawalt 2001, p. 60).

In his Serbian National Songs, the most well known version of the Kosovo battle narratives is the one mentioned above in which Lazar is preparing for his martyrdom. Greenawalt (2001, p. 54) argues that Karadžić's version is first and foremost about "loyalty, loyalty to Lazar and to the 'honorable cross' even at the price of sure death". Lazar does not become a martyr because he fights for Serbia against a Muslim Ottoman army, but rather because he relinquishes his grasp on earthly power in order to receive heavenly power. He assumes Christ's ideal and is as such portrayed in the classical Eastern Orthodox scheme for prince-martyrs. In this scheme, there exist three major groups of prince-martyrs, with Lazar belonging to the type whom are killed by internal or external enemies but humbly accept their fate like Christ. This type is called the suffering ruler.

Secondly, according to Greenawalt (2001), the poem is also about who shall rule Serbia and collect taxes, and, finally, about which of the Serbian or Ottoman warriors fight valiantly on the battlefield. Some prime examples of this are the various narratives about Miloš Obilić and the way he succeeds in killing the Ottoman sultan. The Ottoman sultan is not portrayed as an incarnation of evil, but rather is portrayed positively because he fights and dies in battle. He honors the warrior code. In Karadžić's versions of the Kosovo battle, "Kosovo emerges not as a loss to be avenged, not as a wound to be licked, but as a pledge to be remembered" as Greenawalt puts it (2001, p. 54).

\section{Njegošs's Revitalization of the Kosovo Theme}

Karadžić's standardization made the Kosovo theme popular, and the theme was used in a series of plays, poems and paintings following his works. One of the earliest and most influential adaptations was Petar II Petrović-Njegoš's (1813-1851) use of the Kosovo theme in his major epic The Mountain Wreath (1847). Njegoš was both the ruler and Metropolitan of the semi-autonomous region of Montenegro. He was educated by Sima Milutinović, who was a close friend of Vuk Karadžić's and also a major figure in Serbian Romanticism. Njegoš wrote a series of plays and poems, the most well known of which is The Mountain Wreath. This epic is about Njegoš's ancestor Danilo I, who also ruled Montenegro as both a secular leader and a Metropolitan. In the epic, Danilo and his clansmen try to preserve Montenegro as a Christian state, which eventually leads them to slaughter Montenegrin Muslim converts during Christmas. This event is often called the Montenegrin Vesper and is allegedly a historical event (Javarek 1952).

The major part of the epic is devoted to a discussion between Danilo and his clansmen in which they debate and reflect on how and why Montenegro should remain Christian and not succumb to the Muslim Ottoman sultan. The Kosovo theme plays a major role in this debate. 
At the opening of the epic, Bishop Danilo sits alone and yearns for a day when Montenegro will be freed from the Turks. ${ }^{1}$ He calls out for a hero like Miloš Obilić who can save the day. A fellow Montenegrin replies: "The hope we had was buried forever / in one large tomb at the Kosovo Field" (Mihailović 2006, verse 54). Following his monologue, a longer section is devoted to an internal debate amongst the Christian Montenegrins about what to do with "the Turks" in Montenegro. This is followed by a lengthier debate between the Christian Montenegrins and their Muslim counterparts. Danilo tries to win them back to their ancestral faith, but the Muslims reply that they must have been seduced by Miloš's legacy or are just plain drunk (verse 123). A Christian Montenegrin then states:

"But bravery and our Montenegrin name / have risen from Kosovo's tomb again / above the cloud into the knights' kingdom, / where Obilić holds sway over shadows." (Mihailović 2006, verse 130)

The debate ends with no conclusion, and the two groups go their separate ways. Then follows a section describing a gathering of the tribal chieftains of Montenegro, after which they go to sleep and all dream of Miloš and the Kosovo Maidan, who convince them to take the final vow in church on Christmas Day to fight the Turks. The final section of the epic contains a discussion between the bishop and an abbot on Christmas Day, which ends with the news of the Montenegrin clansmen's victory over the Turks, or, to put it bluntly, their extermination of all Montenegrin Muslims. The poem concludes with a Christmas Day service at which the abbot says:

"Listen, people, you all take off your caps! / I want to hold a memorial service / to the souls of our nation's great heroes. / This day will be the most priceless to them. / Since Kosovo there's never been such day." (Mihailović 2006, verse 213)

It is perhaps no surprise that Njegoš's epic is wildly debated and controversial today. There are two major lines of interpretation; one sees the poem critically as a Serbian blueprint for the Christian ethnic cleansing of Muslims, and the other as a much more complex poem about freedom and the primordial fall of man. The critical side has gained momentum, especially after the Kosovo War in 1999, and their main emphasis is that, in Njegoš's epic, the Kosovo myth, national romanticism and Eastern Orthodoxy blend into a dangerous national chauvinist cocktail (Judah 2009; Kühle and Laustsen 2006; Anzulović 1999). Greenawalt (2001, pp. 60-61) sharply notes, along those lines, that

“Njegoš lays out his dark vision of Serbian history. According to the scheme, Serbia's medieval leaders committed the mortal sin of discord and disloyalty. God has punished them through Kosovo, a national fall from grace, which left spaces of identity [ . . . ] But just as humanity can enjoy salvation through Jesus, so too do the Serbs have their national Christ: Miloš Obilić [ ... ] the martyr of national purity, the genocidal Christ"

In such a reading of the epic, the fight between the Christian Montenegrins and Muslims becomes the center of the narrative and mirrors the fight of Lazar and Obilić against the Muslim Turks at Kosovo Polje. This line of interpretation underlines how Miloš Obilić and Kosovo are used to mark the point in time when the Serbian nation fell under Ottoman and Islamic control. In such an interpretation, the major theme is the everlasting battle between the good and loyal Christians and the evil Muslims, in which the Serbs suffer the greatest toll at the frontline in Kosovo. The fight can only end when the Muslims are forced out of Serbian lands. It can only end with a final crusade such as the one in Njegoš's poem.

Against such a reading, other scholars, such as Srdja Pavlović (2001) and Zdenko Zlatar (2007), underline that Njegoš's epic should first and foremost be understood in its right context. It was written

1 Throughout the poem, and in Serbian-Montenegrin folk stories in general, 'the Turks' is a common name for the Ottomans or for Slavs who have converted to the Islamic faith. 
by a secular and religious leader facing severe pressure from the Ottoman Empire, which took the form of local Slavic Muslims acting on behalf of the empire, and he wrote it during a period in which there were several Serbian uprisings. Njegoš spent most of his intellectual life wondering about the nature of evil, and his depiction of it was deeply theological and was not limited to a simple dualistic conception of good and evil (Prvulović 1954).

To interpret Njegoš's epic into today's world of nations and politics is to go far beyond his experience and context, and it thus cannot be the only valid way of interpreting it. The poem is open to a multitude of interpretations in which all regimes since Njegoš's time have been able to find justification for their claims to power-as Pavlović puts it: "every new generation [ ... ] appropriates Njegoš's work hoping to find enough quotations to validate their own views" (2001, p. 5).

Despite the differing interpretations of the epic, it is quite clear that the poem draws an image of the Montenegrin tribes and their bishop's battle which mirrors that of the battle of Kosovo. The Montenegrins' battle and the Kosovo battle both mirror a biblical and universal battle between angels and devils. This battle is fought at the forefront in order to defend Christendom, a collective. It is written, as the dedication in the opening of the epic testifies, to inspire the Slavic struggle for freedom from the Ottomans, such as the Serbian uprisings in 1804-1813 and in 1815-1817. The focus of the epic is the heroic and sacred fight of the Montenegrin tribes against overwhelming enemies and the lure of the Muslim faith, which promises them peace and prosperity if they leave their ancestral faith. For Njegoš, this theme is one that repeats itself in mankind's history: first at the primordial fall, then for Christ, then at Kosovo Polje for Prince Lazar and Obilić, and finally for Danilo and the Montenegrin chieftains. All are tempted and stand their ground (with the significant exception of Adam). The bishop, Danilo, conjures this image in the poem when he addresses the Ottoman sultan:

"you insult God from the holy altar, / a mosque rises where the broken Cross lies. [ ... ] / Behold the work of that wicked monarch, / whom the devil teaches all kinds of things: / "Montenegro I cannot win or tame, [ ... ] / And so began the devil's Messiah / to offer them sweetmeats of his false faith. / May God strike you, loathsome degenerates, / why do we need the Turks' faith among us? / What will you do with your ancestors' curse? / With what will you appear before Miloš [Obilić]" (Mihailović 2006, verse 40-46)

However, it is not so obvious who this collective Christian "we" is and who is the collective that is being defended. In the epic, the various characters often speak of the Serbian and/or Montenegrin collective, and it is this "we" (often referred to as the plemena, a Serbian word for tribe) that is under threat when Slavs convert to Islam. The protection does not seem to be for the whole of Christendom-at least not the Roman Catholic parts-but rather exclusively for the tribe that could be considered as the Serbians, whose national character is defined, in Njegoš's perspective, only by their Orthodox faith. The Montenegrins who converted to Islam are referred to in the poem by a derogative slur for Slavs that convert to Islam, and it is them that are the target for the slaughter at the end of the epic. Danilo and others talk of their opponents as disloyal brothers, not as foreigners from Anatolia-e.g., "A brother will slaughter his own brother" (Mihailović 2006, verse 47). This also applies to the Kosovo battle, which is not framed in the poem as a battle to protect the West or Christendom, but rather one for the defense of the Orthodox faith—a battle that made the Serbian "tribes" take the Kosovo pledge to forever defend their ancestral home and church. In Njegoš's work, the continual battle would only be lost if the Serbian tribes failed to unite and fell into discord as they had done at Kosovo field in $1389 .^{2}$

2 The "chorus" (Kolo) of the epic spells out this theme in verses 60-68, which seems to repeat the same moral as Karadžić's version of the Kosovo poem: "Our own leaders, miserable cowards, / thus became the traitors of our nation. / O that accursed supper of Kosovo!" [verse 60] ... "God is angry with the Serbian people. / A dragon with seven heads [verse 68] has appeared and devoured the entire Serbian nation [verse 69]." Ibid. The word nation in these verses is a translation of the Serbian word plemena, but Vasa D. Mihailović has been criticized for this translation by Srdja Pavlović (2001, pp. 6-7), because a more standard translation would be "tribe" rather than nation. Pavlović sees it as a way that nationalism is inserted into the work. 
The warriors of the Montenegrin clans might be called Christian holy warriors (a variant of crusaders) imitating Christ in a just and holy war in the epic, but they seem to fight only for the Orthodox world.

\section{The Serbian Orthodox Church on Kosovo}

Njegoš's and Karadžić's works became extremely influential in the Serbian Orthodox Church's revival of Kosovo narratives in the beginning of the twentieth century. The structure of a bulwark myth can be found in these works, though that is not the case in the original Serbian sources which were more preoccupied with the elevation of Lazar to sainthood. The influence of Njegoš's and Karadžić's works came about due to their use by Metropolitan Nikolai Velimirović (1880-1956) who was one of the SOC's leading theologians in the period between the two world wars. Velimirović's views on Kosovo were born out of Njegoš's and Karadžić's works. They were then passed on from him to the leading clergy of the present-day SOC, whom were taught his works by his pupils, such as Justin Popović (1894-1979), and so this line of thought became a cornerstone of the SOC after the fall of communism (Buchenau 1999, pp. 11-15).

The prominence of the Kosovo narratives in contemporary Serbia is linked with the roles Kosovo and the battle play within the SOC. It is from the church that essential parts of the Serbian national identity were formed, and from there that the imagery and symbols of Kosovo were preserved and kept alive (Judah 2009). As the influential scholar on the Balkans and religion Vjekolsva Perica (2005) notes, the narratives of Kosovo as Serbia's cradle and the mythologization of the battle of Kosovo Polje were first popularized to the masses in the early 1900s to 1930s, as part of the SOC's revival of the cult of Lazar during the time of Velimirović. From 1939 onwards (the 550th year anniversary of the battle), 14 June has been celebrated as St. Vitus Day, and, from then on, the church has marked the battle yearly. Until then, the cult of Lazar was only confined to the monasteries in Ravinca, where his body was kept. Perica (2005, p. 135) notes that the renewal of the cult around the Kosovo battle in 1939 was not intended to be one based on an antemurale myth. It was instead renewed in order to highlight the Serbian golden age, which was imagined to be under the Nemanjić's medieval rule and during the formation of the medieval Serbian church under St. Sava. The Kosovo battle marked the end of this era and the beginning of Ottoman rule, which finally ended with the liberation of Serbia in the nineteenth century and the conquest of Kosovo in 1912. The Kosovo myth was, at that time, much more the myth of a golden age that ended when the Serbian lords began to fight amongst each other, and, divided, were conquered one by one by the Ottomans. The Serbians were not defenders on a bulwark nor sacred warriors, but a people disunited and thus ready to fall. Lazar is glorified as the last Serbian lord, who tried to unite the quarrelling lords, but was slain due to their betrayal. His sacrifice did, however, save the SOC from destruction, and the church was preserved under Ottoman rule until the Great Migration. This is the tale of a martyr-nation, not a crusader one.

The formation and spread of this particular interpretation of Serbian history and Kosovo after 1912 is well documented by Florian Bieber (2002), and it became the backdrop which the Serbian nationalists used in the 1990s. As Jason A. Edwards (2015) concludes, the Milošević regime's use of the Kosovo myth was not strictly following an antemurale scheme. The Kosovo narratives were also blended with other types of myths and used in order to underline the suffering of the Serbs (martyrdom), the heroism of their warriors, and their claim to Kosovo, because the Serbs were supposedly driven from their cradle there (the antiquity myth). In this self-image of a suffering nation, Kosovo was presented as a place that needed to be defended against the Muslim Albanian extermination of the Kosovo-Serbs. In this way, Kosovo was portrayed as a bulwark the Serbs had pledged to defend, not for the West or Christendom in general, but for the sake of the Serbian Orthodox nation. As Milošević said in his most famous speech at the $600^{\text {th }}$ year anniversary of the battle at Kosovo field: if Kosovo were to fall, the Serb nation would fall into chaos. Kosovo was a Serbian bulwark securing the order of the nation. Again, this is the image of a suffering martyr-nation, but with substantial elements of the antemurale myth, because the nation is called upon to defend order against chaos in a new battle (Perica 2005, p. 132; Ramet 1995). 


\subsection{The Narratives of Kosovo in the 1980s}

The backdrop of the Milošević regime's use of Kosovo dates back to the early 1980s, well before a broad Serbian nationalist movement caught on. In 1982, the SOC voiced concern about Kosovo in an appeal to the public signed by 21 clerics, amongst which were four future central metropolitans. This became the first sign of the revitalization of the Kosovo narratives and Serbian nationalism in Socialist Yugoslavia which had for so long kept them in check (Buchenau 1999). The appeal foreshadowed what was about to come. It voiced concern over the slow migration of Serbs from Kosovo and the subsequent Albanian demographic takeover that had been underway since the Second World War. In the appeal, the Kosovo narratives play a vital role because Kosovo is stressed as the cradle of the Serbian nation, and the battle in 1389 is argued to be a continual one still ongoing in Kosovo. The Serbs of Kosovo are, according to the appeal, still fighting for their survival, holding on to "the last remains of the cross and the last standing of the Serbian people" (Buchenau 1999, p. 17). The appeal calls for the protection of the Serbs or, otherwise, a "slow, but well planned genocide" of the Serbs will take place in Kosovo (Buchenau 1999, p. 18).

Following the appeal, a petition was delivered to the highest state institution in Yugoslavia in 1985, signed by 2,016 Kosovo-Serbs, calling for a halt of "Albanian chauvinism" in Kosovo. The petition was supported by a declaration of solidarity by 212 Serbian intellectuals and clerics, further highlighting the question of Kosovo and calling for the protection of "the Serbian people and their history" (Buchenau 1999, p. 21). These calls initiated a decade of writing on Kosovo, both by clerics and Serbian intellectuals, all participating in stirring awake the Serbian national consciousness. The Kosovo narratives began to take on a deeper religious and national tone, according to Klaus Buchenau's (1999) thorough investigation. A prime example of this is a 1989 text on Kosovo by Matija Bećković in which he writes:

"Kosovo is the costliest Serbian word. It is paid for with the blood of a whole people. For the price of the blood of the people it is crowned at the throne of the Serbian language. Without blood it couldn't have been bought, and still be bought [ ... ] Kosovo is the Serbian history of the deluge: the Serbian New Testament" (Quoted in Buchenau 1999, p. 24)

In Bećković's words, Kosovo becomes a covenant of blood in which the Serbs have fallen and shall rise again. Kosovo mirrors biblical history. Mankind fell from grace in the primordial fall and became one with God again through Christ's resurrection. The Serbs mirrored this when they lost at Kosovo Polje, but they have the chance to redeem themselves again, if they honor the Kosovo covenant and defend their church and ancestral home. The new fight is a defense of the Serbian control over Kosovo against a Muslim Albanian takeover. This is a fight on the bulwark of the Serbian nation, combined with a collective martyrdom myth and a myth of the ancestral home (the antiquitas). Bećković's and other Serbian writers' and clergy's texts on Kosovo became the fuel which the Milošević regime used to mobilize the Serbs for the wars that followed in former Yugoslavia (Buchenau 1999). In this period, the image of Kosovo was enlarged. Suddenly, the region of "Krajia" (the formerly Serbian populated part of Croatia) was, every so often, refered to as the "Western Kosovo". In such texts, Kosovo became the image of the walls of the Great Serbian Nation that needed to be defended from all the foreign threats: Catholics, Muslims, or whomever stood in the way (Buchenau 1999, pp. 26-27). War then eventually came and inflicted heavy tolls on the Serbs, especially the ones on the "frontiers" of "Great Serbia"; in Croatia (the region "Krajia" literally means border) and parts of Bosnia in 1991-1995, and finally in Kosovo in 1999.

\subsection{The Narratives of Kosovo around 1999}

In the years leading up to the Kosovo War in 1999 and following it, the SOC lost faith in the Milošević regime's policies in general and in Kosovo in particular. Several central clerics, amongst them the metropolitan of a central metropolitanate in Kosovo, began to criticize the regime openly as early as 1996, and sought other solutions that might ensure the Serbian presence in Kosovo and the 
protection of the SOC's sites there (Buchenau 1999, pp. 31-42). In the aftermath of the war, the SOC produced two central books, in Serbian and English, calling for international protection of the sites and of Serbs in Kosovo, which also articulated another changing conception of Kosovo. In the opening statement of one of the books, known as the SOC's Memorandum on Kosovo and Methohija (2003), the synod of the SOC's bishops writes:

"Kosovo and Methohija, the Holy Land of the Serbian people. What Jerusalem means to the Jewish people, that is Kosovo for the Serbs. Moreover, Kosovo, like Jerusalem, is not just a matter of geography or demography. It is a question of identity" (SOC Serbian Orthodox Church, p. 9)

It goes on to say:

"It is in fact the centuries-old Serbian Kosovo Covenant [that is] the expression of our human and Christian memory ..." (SOC Serbian Orthodox Church, p. 16)

In this memorandum, Kosovo is equated with Jerusalem and the fate of the Serbs is made equal to that of the Jews; a tale of suffering and martyrdom. In the text, it is argued "the myth of Kosovo" exists more in Western academic writings than in Serbian religiosity (SOC Serbian Orthodox Church, pp. 15-17). The SOC explicitly states in the memorandum that the SOC itself is built on a Kosovo covenant, which is founded on Kosovo and Methohija's status as the ancestral home of ancient Serbia and the historical center of the patriarchate. In the church's opinion, this covenant has less to do with nationalism and the "Kosovo myth", but more to do with their concrete ownership of-in their estimation-more than 1,300 churches and monasteries in the region, and the need to protect them. According to Zorica Kuburić (2014), the Kosovo narratives in the SOC since 1999 present an image of Kosovo as a holy land that needs to be protected. What is essential is not whom the land has to be protected from, but rather that the Serbs in general have pledged to do so. As Kuburić (2014, p. 145) puts it:

"The overlapping of the religious and national identities, as well as the connections between the Church and the state, make it difficult to separate religious issues from political ones. [... ] The members of the Serbian Orthodox Church are determined to protect their graves, to not betray the faith of their ancestors, and to not leave the country which is both their home and their tomb. The power of the collective unconscious rises from the Kosovo pledge."

In the SOC's memorandum, it is not just the Turks or the Muslim Albanians that are viewed as a threat, but "Anglican-American"- and NATO-backed interference as well. The SOC moves even further and also draws attention to the suffering of the Serbs and the Orthodox community under communist (1945-1989) and Nazi-fascist rule (1940-1945). ${ }^{3}$ In this memorandum, Kosovo becomes a sacred city in dire need of protection.

The SOC's views on Kosovo are sharpened in the SOC book Crucified Kosovo (1999), which was a draft for the memorandum. In this volume, two metropolitans, the SOC's patriarch and others seek to raise national and international awareness on the SOC's threatened position in Kosovo. The book was published only a few months after the war ended in 1999 and much of it is simply devoted to highlighting the destruction and desecration of SOC property in Kosovo. It consists of the bishop's speeches during an event raising awareness of the destroyed churches. The contributions in the book all call for help to restore the shrines and protect them from further destruction, but at the same time criticize the foreign troops of the NATO force, the Albanians, and the Milošević regime in Belgrade for not doing enough or not doing the right thing. In this volume, one of the central metropolitans, Amfilohije, speaks plainly about Kosovo. He argues that the experience in Kosovo is following the pattern of the Kosovo battle. He says: 
"We are fighting, [ ... ] a new Kosovo battle, but this time we have no venerable Prince and no Holy Cross. The venerable Knez has been replaced by irreligion. Irreligion, as known to people from times immemorial, lacks in faith. The Holy Cross has been substituted for a "target" [ ... ]. It has also been replaced by an Albanian flag that is now, for the first time since the Battle of Kosovo, flown from the house nearest to the Patriarchate." (SOC Serbian Orthodox Church)

Metropolitan Amfilohije thus puts the recent war in Kosovo into the context of Serbian history. The Serbs and the SOC have lost because they lack a true leader fighting under a true banner. There is no Prince Lazar to fight a Kosovo battle. Instead, the Serbs are left with "irreligion". Amfilohije thereby implies that Milošević and his regime are seen as illegitimate. The illegitimacy of Milošević is contrasted to the legitimacy of Prince Lazar. In such a view, Milošević sacrificed Kosovo for his own safety, whereas Lazar sacrificed himself for the benefit of the Serbs. Amfilohije therefore argues that the Serbian loss is another test in God's vision of the world. Once more, the Serbs must suffer in hope of a future heavenly kingdom. Amfilohije notes:

“Today's verdict, being passed on the world, was written in a gospel before Christ's Golgotha, and its continuation, I have a feeling, coincides with what is going on in Kosovo and Metohija at present." (SOC Serbian Orthodox Church)

Here, he links the suffering of Christ together with the suffering of the SOC in Kosovo. It is not only Kosovo that is being crucified, but also the SOC and the Serbs. The only solution is:

"to find new ways out of this misery, the Kosovo straits, depends on God and God's intentions but also on us all." (SOC Serbian Orthodox Church)

It is only possible for God to stop the suffering of the SOC and the Serbs, if God and the SOC once more can become one. In the memorandum (SOC Serbian Orthodox Church) and the book Kosovo crucified (SOC Serbian Orthodox Church), it is argued a pattern of history is repeating itself. The suffering repeats itself from the primordial fall, to Christ on Golgotha, to Kosovo Polje, and onto Kosovo in 1999. It becomes in these new texts a continual tale of suffering and martyrdom, not one of resurrection and victory. The patterns of resurrection and successful valiant defense in Njegoš's and the SOC's writings on Kosovo in the early and late twentieth century seem to have been de-emphasized after the 1999 war. The harsh reality of the Serbian failure in Kosovo seems to have reached the SOC (Buchenau 1999, pp. 31-35).

Following the Kosovo War, the Milošević regime was overthrown in Serbia in October 2000, a foreign NATO force was deployed in Kosovo, and the Albanian-led Kosovo government unilaterally declared Kosovo independent in 2008 (see Di Lellio 2006). These major geo-political changes have reinforced the changed narrative of Kosovo that resurfaced in the SOC during the war in 1999. The resurrection, blood and war metaphors are being replaced with a narrative of suffering and martyrdom. Kosovo is no longer a place for a physical fight but is stressed in the SOC's recent publications as the "Old Serbia" that needs protection and safekeeping, a sacred city under threat that needs spiritual sacrifice. This safekeeping is the reframed Kosovo "pledge", and Kosovo is frequently talked of as the Serbian Jerusalem. There seems to have been an Old Testament reframing of Kosovo from 1999 onwards. One of the newest examples of this is a series of open letters, appeals and messages from the SOC from 2018, when the Kosovo-Albanian and Serbian governments held, under EU auspice, renewed talks on the future of Kosovo. A major theme in these talks was the possibility of exchanging municipalities between Serbia and Kosovo in order to let Serbian-dominated provinces become part of Serbia proper as a sort of compensation to Serbia for its acknowledgement of Kosovo's independence. During these peace talks, the SOC fiercely opposed the exchange and the acknowledgement of Kosovo's independent status, and the Kosovo narratives were used as a point of departure into why the SOC would not accept the exchange. In a message from the SOC's bishop assembly on Kosovo on 13 May 
2018, it is stressed from the start that Kosovo is the founding place of the SOC and that it is where a significant part of its churches and monasteries are. Kosovo is an "inalienable central part of Serbia" (SOC Serbian Orthodox Church). According to the bishops:

"The Kosovo Testament signifies the expression of the central message of the New Testament. Concretely, experienced in the historical experience of the Serbian people [...] it is neither a question of national ideology or mythology [... but a] cornerstone of its identity, history and statehood." (SOC Serbian Orthodox Church )

They go on to say:

"In [ ... ] division, the people would automatically be left to the mercy and mercilessness of the regime of the so-called state of Kosovo; exposed to a pogrom similar to that of March 2004 or, under pressure and quiet terror, would be forced into an exodus." (SOC Serbian Orthodox Church)

In November 2018, the assembly of all the SOC's bishops issued a second statement in which they once again voiced concern over Kosovo. The bishops stated that they supported the SOC in Kosovo and the Serbs "to persist and remain in Kosovo and Metohija, the heartland of the Serbian Orthodox spirituality and our identity" (SOC Serbian Orthodox Church). The bishops warned again that Kosovo is a "question of the survival of our clergy, monastics, and the faithful people, and, especially, our ancient holy sites without which we never would have become what we are today" (SOC Serbian Orthodox Church). What becomes clear in these statements released by the SOC during the peace talks of 2018, is that the Kosovo narratives of the battle have been de-emphasized. There is no talk of a wall, a fight for Western civilization, or even any battle at all, neither physical nor spiritual. Instead, Kosovo is emphasized as the SOC's and the Serb's homeland, and a place for their holy shrines. A place they might be forced away from in another "exodus". The Kosovo narratives of today could therefore rather be labeled as a mixture of the antiquity myth and that of martyrdom. The blend corresponds to that of the Jewish suffering in the Old Testament, and the SOC frequently alludes to this theme through the use of "exodus", "pogrom", "Jerusalem" and "ancient shrines". The suffering of the Serbs in Kosovo is talked of in a manner similar to that of the Old Testament's world of suffering, joined by a few references to the death and suffering of Christ. It does, however, still contain an idea of entitlement to the soil and of salvation in which the basic core of the antemurale myth is preserved. The brute force and open spilling of blood has ended in this image, but a slow, silent and even more threating Exodus of the Serbs is beginning to unfold.

\section{Concluding Discussion of the Antemurale Myth Today}

First of all, there is a rich supply of evidence that in the 1980s and 1990s, a sort of antemurale myth was used by the Milošević regime during the Serbian mobilization for the wars to come during the dissolution of Yugoslavia. This was not an image of holy victorious crusaders, but rather one of a suffering nation remembering its pledge to defend its home from chaos. The theme of antemurale seems to have been reshaped by some members of the SOC's clergy in the early 1980s as part of the general trend in the reawakening of the Serbian nationalist movement throughout Serbian society. In this image, the Serbs were fighting for the Christian faith mainly against the Muslim—and imagined "Turkish" —-threat in Kosovo and Bosnia. However, the core narrative of this awakening was not that of a battle between the West and the East nor between Christendom and Islam. The narrative was rather that of Kosovo being the cradle of the Serbs, which they had been driven from forcefully in a series of "exoduses". In the perhaps most central document of the Serbian nationalist reawakening, The Memorandum of the Serbian Academy of Sciences on Kosovo and Arts (Serbian Academy of Sciences and Arts 1986), Kosovo is talked of as a "cradle", and a Serbian "exodus" is mentioned, but there is no reference to the battle in 1389. However, the Serbs were called upon to fight for Kosovo because it was their homeland and their border with the Albanians, but that was in the same manner as they were called upon to fight 
in Krajina in Croatia (Western Kosovo). Elements of the antemurale were present, but it was not an image of the Serbs as defenders of another whole (Christendom or the West); they only fought for the protection of Serbia and the Serbian Eastern Orthodox Church.

The elements of war, a wall, and valiant warriors at Kosovo Polje were further de-emphasized by the SOC in the years leading to the 1999 Kosovo War and since. The narrative of Kosovo was narrowed to a biblical one of suffering, martyrdom, and divine right to a sacred homeland-a Jerusalem. The myth of old Serbia (the antiquity myth) has been more important for the SOC in the past twenty years.

The two major seminal works expressing the Kosovo narratives from the nineteenth century, Karadžić's and Njegoš's, did, however, contain elements of an antemurale myth. These elements were reactivated during the years of the Milošević regime. It is crucial to note, however, that these structures of the antemurale myth do not seem to have been present, or at least were not of interest for the early Serbian sources, who, unlike the Catholic sources, were more concerned with the elevation of Lazar to sainthood. In Karadžić's work, the narrative was mostly that of martyrdom and an image of the valiant Serbian knights fighting for freedom. This fight took on the biblical form and scheme of an imitation of Christ, and, in doing so, created a dramatic dualism between the good loyal Serbian knights protecting their people, and the opposing disloyal Serbian lords. It thus took the form of a general Eastern European image of the valiant warriors on the wall. The Muslim Turks do not appear as the main evil characters of the epic, but rather as God's tool to punish the Serbs. Despite this, the Kosovo battle contains, in Karadžićs s version, metaphors of blood, sacrifice, Christendom versus Islam, and Serbian knights elected by God. All the elements that could be used to form the antemurale myth of Kosovo were used again by the Milošević regime.

The same dramatic dualism also appears in Njegoš's poem as the epic casts the loyal Christian Montenegrin tribes against the disloyal Muslim Montenegrin converts. Kosovo becomes here, for one of the first time, a metaphor for a pledge to protect the Serbian ancestral faith. Since Njegošs's poem operates with a theological mirroring of the earthly realm with that of the heavenly, so that the Montenegrin Christians' fight mirrors the Angels' fight against the Devils, it creates a dualism between Christendom and Islam. In this narrative, which Kolstø (2005) describes as a "martyrological version [of] the antemurale myth [which] acquires messianic overtones", the Montenegrin people are cast in the role of what Greenawalt (2001) calls "the martyr of national purity, the genocidal Christ". This is a reading that takes Njegoš's epic too far in my opinion, but a reading some Serbian nationalists might agree with. It does point to a potential Serbian national self-image based on Njegošs epic, in which the Serbs defend a Christian wall against the Muslims. This potential was exploited to its fullest extent by the Milošević regime and the Bosnian-Serbian leader during the war in Bosnia. ${ }^{4}$

A striking conclusion is that the Serbian antemurale theme in the various narratives on Kosovo rarely frames the Serbs as defenders of anything other than Serbia itself. It is only in Njegošs's epic that the Universal Christian world enters the cosmology. Kosovo is often just the border of Serbia, just like Krajina in Croatia is. It is a bulwark for the Serbian nation and for Orthodoxy, but not for the whole of Western Christian civilization. There seem to be sound geo-polititcal, historical, and theological reasons for this. First, there is a deep theological divide between the Eastern Christian Serbs and the Catholic West from the medieval period onwards. This divide is further fueled by the threat the Catholic Church posed to the Orthodox Christians during the aggressive Catholic missions in the period of the Venetian control of Dalmatia and the Montenegrin littoral, as well as during the Fourth Crusade that pillaged the spiritual heart of Orthodoxy, Byzantium (1453). This divide became even more apparent when Serbian lords aided the Ottomans against the Catholics in both the failed Crusade of Varna (1443-1444) and the Second Battle of Kosovo (1448) (Malcolm 1999). During these two crusades, it seems that the Serbian lords preferred Ottoman rather than Catholic suzerainty.

4 See, for example, the Bosnian Serbian president during the Bosnian wars Radovan Karadžić's text (Karadžić 1995), "Da li je ovo bio rat?" [Eng.: Was this a true war?] 
This divide was widened in the founding days of the Serbian nation-state in the nineteenth and twentieth centuries. There was widespread skepticism in the Orthodox Church of the liberal Catholic and Protestant West. Velimirović and other leading conservative theologians saw the West as a decadent and schismatic form of Christendom (Buchenau 1999). This point of view was passed on to his pupils, and to the Orthodox theologians of today, further fueled by the general Eastern Orthodox skepticism of the West. In the eyes of many Serbian Orthodox, there is only one true form of Christianity, and it does not include the West.

Secondly, the Serbian nation-state was, from its foundation, under pressure from the West in the form of the Habsburg Austrian-Hungarian Empire. In the two World Wars, Serbia was attacked by the West, by either Austrian, German, or Italian forces. The massive extermination of Orthodox Serbs during the Croat Ustashe-fascist regime during the Second World War is perhaps an even stronger myth and fear in Serbian society, which perhaps played an even more crucial role in the wars in the 1990s (Perica 2005). The Balkan wars of the 1990s followed the same pattern, reinforcing anti-Western sentiment. The USA aided the Bosnians and Croats and intervened in Kosovo against the Serbs. Geo-politically and historically speaking, the Serbs have often experienced violence both at the hands of Western as well as Turkish armies. Therefore, it makes sense that the collective "we" in the Kosovo imagery, which needs to be defended by the Serbs, rarely includes the West or the Catholic Christians. When the "we" is enlarged, it more often includes Russia, Serbia's longtime ally, and a country that shares with it both the Orthodox faith and the skepticism of the West.

However, there has been a change of tack in the SOC's publications and actions since the period leading up to the 1999 Kosovo War until the present day. Remarkably, most of their texts are published in both Serbian and English, and the SOC is making a substantial effort to distance itself from the Milošević regime during the 1997-1999 period. These texts and addresses are directed to a broader global audience, and the battle as well as the antemurale themes are not emphasized. Instead, the suffering (martyrdom) and the historical heritage (antiquity) of the Serbs are put to the forefront. They are appealing to Western Christian civilization to remember their common history with the Orthodox Serbs, and perhaps aid them accordingly.

Funding: This research was partly funded by C.E.Gads Foundation, whose travel grant (2017) was used for field studies and meetings with the Serbian Orthodox Church in Montenegro in 2018.

Acknowledgments: The author would like to acknowledge the contribution of Ass. Professor Carsten Selch, who suggested the overall theme and gave valuable input along the working process of this paper. I the same manner, Tarek Salhany are acknowledged for his valuable linguistic and grammatical input, as well as his proofreading of this paper.

Conflicts of Interest: The author declares no conflict of interest.

\section{References}

Amfilohije, Metropolitan. 1999. Shame and Blame in the Face of Christian Europe in Crucified Kosovo, Belgrade. Available online: http://www.kosovo.net/crucified/sp-amfilohije.html (accessed on 22 August 2019).

Antic, Ana. 2005. The Evolution of the boundary: Defining historical myths in Serbian academic and public opinions in the 1990s. In Myths and Boundaries in South-eastern Europe. Edited by Pål Kolstø. London: Hurst \& Co., pp. 191-93.

Anzulović, Branimir. 1999. Heavenly Serbia—From Myth to Genocide. London: Hurst \& Company.

Bieber, Florian. 2002. Nationalist Mobilization and Stories of Serb Suffering: The Kosovo myth from 600th anniversary to the present. Rethinking History 6: 95-110. [CrossRef]

Buchenau, Klaus. 1999. Verspäete Ernüchterung_Die Serbische Orthodoxe Kirche im Kosovokonflikt 1960-1999. In Die Serbische Orthodoxe Kirche im Kosovokonflikt. Krieg auf dem Balkan. Edited by Klaus Buchenau and Stefan Troebst. Berlin: Arbeitspapiere des Osteuropa Instituts, Frie Universität Berlin, no. 2.

Di Lellio, Anna, ed. 2006. The Case for Kosova: Passage to Independence. London: Anthem Press.

Edwards, Jason A. 2015. Bringing in Earthly Redemption: Slobodan Milosevic and the National Myth of Kosovo. Advances in the History of Rhetoric 18: 87-204. [CrossRef] 
Goldstein, Iva. 2005. The Boundary of the Drina: The meaning of and development of a mythologeme. In Myths and Boundaries in South-eastern Europe. Edited by Pål Kolstø. London: Hurst \& Co., pp. 77-105.

Greenawalt, Alexander. 2001. Kosovo Myths: Karadžić, Njegoš, and the Transformation of Serb Memory. Spaces of Identity 3: 51. [CrossRef]

Housley, Norman. 2003. Religious Warfare in Europe, 1400-1536. Oxford: Oxford University Press.

Huntington, Samuel P. 1993. The Clash of Civilizations? Foreign Affairs 72: 22-49. [CrossRef]

Huntington, Samuel P. 1996. The Clash of Civilization and the Remaking of World Order. New York: Simon \& Schuster. Javarek, Vera. 1952. Petar Petrović Njegoš (1813-51). The Slavonic and East European Review 30: 514-30.

Judah, Tim. 2009. The Serbs. New Haven: Yale University Press.

Karadžić, Radovan. 1995. Da li je ovo bio rat? [Ewar] in Jagnje Božije i Zvijer iz bezdana [The lamb of god and the beast from the abyss], Cetinje, Svetigora. Available online: https:/www.rastko.rs/filosofija/jagnje/index.html (accessed on 22 August 2019).

Kolstø, Pål. 2005. Introduction: Assesing the Role of Historical Myths in Modern Society. In Myths and Boundaries in South-eastern Europe. Edited by Pål Kolstø. London: Hurst \& Co., pp. 1-34.

Kuburić, Zorica. 2014. Serbian Orthodox Church in Kosovo and Metohija: Between Past and Future. Balkan Journal of Philosophy 2: 137-46. [CrossRef]

Kühle, Lene, and Carsten Bagge Laustsen. 2006. The Kosov Myth: Nationalism and revenge. In Kosovo between War and Peace-Nationalism, Peacebuilding and International Trusteeship. Edited by Tonny Brems Knudsen and Carsten Bagge Laustsen. London and New York: Routledge, pp. 37-56.

Malcolm, Noel. 1999. Kosovo-A Short History. London: Macmillan Press.

Matthias, John, and Vladeta Vuckovic, trans. 1989, The Battle of Kosovo-Serbian Epic Poems. Athens: Swallow Press/Ohio University Press, Available online: http://www.kosovo.net/history/battle_of_kosovo.html (accessed on 22 August 2019).

Mihailović, Vasa D., trans. 2006. The Mountain Wreath. Available online: https://web.archive.org/web/ 20090226210356/http://www.rastko.org.rs/knjizevnost/njegos/njegos-mountain_wreath.html22.08.2019 (accessed on 22 August 2019).

Mylonas, Christos. 2003. Serbian Orthodox Fundamentals— the Quest for an Eternal Identity. New York and Budapest: Central European University Press.

Pavlović, Srdja. 2001. The Mountain Wreath: Poetry or a Blueprint for the Final Solution? Spaces of Identity 1: 4. Pavlovich, Paul. 1989. The History of the Serbian Orthodox Church. Ontario: Serbian Heritage Books.

Perica, Vjekoslav. 2005. The Sanctification of Enmity: Churches and the construction of founding myths of Serbia and Croatia. In Myths and Boundaries in South-eastern Europe. Edited by Pål Kolstø. London: Hurst \& Co., pp. 137-50.

Prvulović, Žika Rad. 1954. Njegoš on the Origin of Evil. The Slavonic and East European Review 32: 406-23.

Ramet, Sabrina P. 1995. The Serbian Church and the Serbian Nation. In Beyond Yoguslavia: Politics, Economics and Culture in a Shattered Community. Edited by Sabina P. Ramet and Ljubisa S. Adamovich. Boulder: Westview Press, pp. 101-22.

Ramet, Sabrina P. 2005. Thinking about Yugoslavia: Scholarly Debates about the Yugoslav Breakup and the Wars in Bosnia and Kosovo. Cambridge: Cambridge University Press.

Serbian Academy of Sciences and Arts. 1986. The Memorandum of the Serbian Academy of Sciences and Arts on Kosovo. Available online: http://www.trepca.net/english/2006/serbian_memorandum_1986/serbia_ memorandum_1986.html (accessed on 22 August 2019).

SOC (Serbian Orthodox Church). 1999. Crucified Kosovo. Belgrade. Available online: http://www.kosovo.net/ crucified/sp-amfilohije.html (accessed on 22 August 2019).

SOC (Serbian Orthodox Church). 2003. Memorandum on Kosovo and Metohija-The Holy Assembly of Bishops of The Serbian Orthodox Church. Belgrade: The Holy Synod of Bishops of The Serbian Orthodox Church.

SOC (Serbian Orthodox Church). 2018a. Message of the Holy Assembly of Bishops on Kosovo and Metohija. May 13. Available online: http://www.spc.rs/eng/message_holy_assembly_bishops_kosovo_and_metohija (accessed on 22 August 2019).

SOC (Serbian Orthodox Church). 2018b. Communique of the Holy Assembly of Bishops of the Serbian Orthodox Church on Kosovo and Metohija. November 8. Available online: http://www.spc.rs/eng/communique_holy_ assembly_bishops_serbian_orthodox_church_kosovo_and_metohija (accessed on 22 August 2019). 
Wilson, Duncan. 1970. The Life and Times of Vuk Stefanović Karadžić 1787-1864: Literacy, Literature, and National Independence in Serbia. Oxford: Clarendon Press.

Zanic, Ivo. 2005. The symbolic identity of Croatia in the Triangle Crossroads-Bulwark-Bridge. In Myths and Boundaries in South-eastern Europe. Edited by Pål Kolstø. London: Hurst \& Co., pp. 35-76.

Zlatar, Zdenko. 2007. The Poetics of Slavdom. Vol. II. Franfurt and Main: Peter Lang.

(C) 2019 by the author. Licensee MDPI, Basel, Switzerland. This article is an open access article distributed under the terms and conditions of the Creative Commons Attribution (CC BY) license (http://creativecommons.org/licenses/by/4.0/). 